\title{
ARTICLE \\ Administrative Law as a Dual State. Authoritarian Elements of Administrative Law
}

\author{
Bas Schotel ${ }^{1}$ (D)
}

Accepted: 1 April 2021 / Published online: 10 May 2021

(c) The Author(s) 2021

\begin{abstract}
Scholars have recently shown how in Europe regimes in democratic decay (e.g. Poland, Hungary) take all sorts of measures targeting and marginalizing political opponents. Although they are authoritarian by nature, the measures are cast in a legal form. According to some scholars this kind of authoritarian rule of law can be best understood as a dual state, namely a combination of the normative state (the rule of law) and the prerogative state (the pure-political or arbitrary-will of those in power). Building on these insights, the present paper makes two new observations. First, administrative law is distinctively well suited to cater for the creation of a dual state. By distinctively I mean better than civil and criminal law. In fact, I argue that administrative law constitutes a dual state in and of itself combining normative and prerogative state elements within a single area of law, in ways that cannot be done under civil and criminal law. Second, not only regimes in democratic decay but also liberal democracies make use of the dual state nature of administrative law. The paper illustrates this point with two techniques whereby liberal democracies use administrative law to circumvent or pervert the normal operation of criminal law, namely crimmigration and the alien detention of citizens. My underlying normative point is to draw attention to the inherent authoritarian potential of administrative law.
\end{abstract}

Keywords Authoritarian rule of law $\cdot$ Dual state $\cdot$ Administrative law $\cdot$ Europe

I received invaluable comments and suggestions on this article and previous versions from Kati Cseres, Tom Daly, David Dyzenhaus, Betty de Hart, Luc Heuschling, Jens Meierhenrich, Joana Mendes, Marcelle Reneman, Thomas Spijkerboer, Béla Strauss, Marc de Wilde, participants of the Bergen aan Zoom conference 2020, participants at the conference in Lund 2020 organized by Vladislava Stoyanova and Stijn Smet and the participants of Centre for Legal Education and Social Theory Reading Group of the University of Wroclaw organized by Michal Stambulski. I am especially grateful to the three anonymous reviewers of this journal who clearly gave the manuscript a charitable, careful but critical reading.

Bas Schotel

b.schotel1@uva.nl

1 Faculty of Law and Paul Scholten Center for Jurisprudence, University of Amsterdam, Amsterdam, The Netherlands 


\section{Introduction}

In the city centre in front of the National Museum, activists organized a blockade to peacefully obstruct traffic and attract as much attention for their protest as possible. The blockade was not authorized by the local authorities and the activists were in violation of the local city ordinance which amounts to a criminal offence. Consequently, 90 activists were arrested and fined under a criminal law procedure, albeit a fast-track one. But 90 were only a fraction of the protesters. The procedures for arrests and fining under criminal law were time-consuming involving paper work as the police have to establish the facts of each individual case. Since the number of protesters did not decrease sufficiently, the mayor issued an emergency order. Rather than arresting and fining the protesters, 270 protesters were put on buses and the buses dropped the protesters a couple of kilometers outside the centre. What matters for the purposes of this paper is that this technique, called 'administrative displacement', is an instrument of administrative law and that the authorities deliberately used administrative law to circumvent the normal application of criminal law. What also matters is that this occurred not in a repressive regime in a distant past, but in the city of Amsterdam in $2019 .^{1}$

In the summer of 1942 the German administration in Belgium ordered the civil police authorities of Antwerp to collect and deport foreign Jews living in Antwerp. ${ }^{2}$ For various reasons the local Antwerp police force were reluctant to participate in these operations. One reason pertained to a formal legal concern. What could possibly be the legal basis in criminal law for the arrests and detentions, as the police could not find a reasonable suspicion of a criminal act committed by the Jewish foreigners? In order to seek legal backing for the operations, a police commissioner reported the operations to the public prosecutor normally in charge of criminal investigations. The public prosecutor did not react to the report thereby signalling to the police officers that he did not legally oppose the operations. Still, the question remained as to the alleged criminal offences committed by the detainees. A way out for the police was to discard criminal law altogether and to treat the operations as only involving administrative arrests and detentions not requiring any reasonable suspicion of a criminal offence.

Recently, scholars examining the emergence of authoritarian rule in Europe have pointed out how contemporary regimes in democratic decay are

\footnotetext{
${ }^{1}$ Het Parool, 'Klimaatprotest ten einde, 90 demonstranten gearresteerd', 7 oktober 2019. https://www. parool.nl/amsterdam/klimaatprotest-ten-einde-90-demonstranten-gearresteerd b3c3905f/?referer=https\% $3 \mathrm{~A} \% 2 \mathrm{~F} \% 2 \mathrm{Fwww}$.google.com $\% 2 \mathrm{~F}$. The legal basis for the administrative displacement is Art. 167a Municipality Act which was originally introduced to combat football hooliganism. The ECtHR ruled that administrative detentions in order to prevent possible future criminal acts need not violate Art. 5 ECHR, even if the detainees are not prosecuted before a criminal court at a later stage. In other words it is permitted to detain a person for alleged criminal acts without a court ordering the detention or judging the merits of the charges. ECtHR, S.V. and A. v. Denmark, 22 October 2018, ECLI:CE:ECHR:2018:1022.

${ }^{2}$ H. Van Goethem, 1942. Het jaar van de stilte, (Polis/Cossee, 2019), Chapters 5, 29 and 48 [ebook without page numbers].
} 
strategically using the law to establish and strengthen their own position while structurally marginalizing the opposition. In fact, according to some scholars authoritarian regimes can be best understood as a dual state, namely a combination of the normative state (the rule of law) and the prerogative state (the pure-political or arbitrary-will of those in power). Contemporary regimes in democratic decay take all sorts of measures to target and marginalize political opponents. Although they are authoritarian by nature, the measures are cast in a legal form. In other words, for the contemporary regimes it is crucial that all their measures have at least the veneer of legality. Building on these insights, the present paper makes two new observations. First, administrative law is distinctively well suited to cater for the creation of a dual state. By distinctively I mean better than civil and criminal law. In fact, I argue that administrative law constitutes a dual state in and of itself combining normative state elements and prerogative state elements within a single area of law, in ways that cannot be done under civil and criminal law. ${ }^{3}$ Second, not only regimes in democratic decay but also liberal democracies make use of the dual state nature of administrative law. Hence the example of 'administrative displacement' in the Netherlands. The underlying normative objective of this article is to urge legal experts to acknowledge and explore the distinctive nature of administrative law and its authoritarian potential.

To clarify matters, I certainly do not claim that administrative law is authoritarian. Neither do I claim that it necessarily leads to authoritarian rule. Nor am I saying that administrative law is sufficient for the creation of authoritarian rule. I am not denying that civil and criminal law have been and can be used for authoritarian purposes. But I do claim that administrative law is distinctly better suited to cater for authoritarian rule than civil and criminal law. If constitutional and fundamental rights constraints are lifted then one finds little to no legal resources within administrative law to resist authoritarian rule. To put it differently, it seems that the authoritarian tactics of regimes in democratic decay only violate constitutional and fundamental rights law, but are completely in compliance with administrative law. So while the regimes may actively pursue a constitutional breakdown, there is no need for them to also undermine administrative law. Apparently, administrative law already suits their purposes just fine.

Administrative law constitutes a dual state because it combines normative state elements with prerogative state elements. The dual state character of administrative law boils down to the fact that while virtually all administrative acts are susceptible to judicial review covering all aspects of the administrative act (law, fact and policy) (normative state), the judicial review is in practice either obsolete or too superficial

\footnotetext{
${ }^{3}$ I am aware that administrative law is not a 'state'. So when I say that administrative law constitutes a dual state, I mean that it combines the elements of the dual state in a single legal field or legal regime. By doing so I can use an existing, albeit adapted, concept, rather than coining a new term. Furthermore, for certain persons administrative law tends to become like a state, as their legal position becomes increasingly governed by administrative law only, e.g. certain aliens.
} 
(prerogative state). This leaves authorities with ample room to take authoritarian measures while benefiting from a legality bonus.

Taking cue from the recent scholarship on authoritarian rule, Section 2 construes the legal order of regimes in democratic decay as a dual state. To this effect the paper will draw on Ernst Fraenkel's concept of the dual state which he used to analyze German law during the Nazi regime and on the recent adaptation of this concept by Jens Meierhenrich. Section 3 seeks to show that administrative law is distinctively well suited compared to civil and criminal law to cater for a dual state. Based on the conventional doctrinal literature on administrative law and comparative administrative law, the Section identifies typical features of administrative law, e.g. the presumption of legality, the privilege of execution, policy discretion and judicial deference to administrative fact-finding. ${ }^{4}$ These typical administrative law arrangements combine normative and prerogative state elements in a single field of law. Section 4 will illustrate the central claims of the paper with examples of legal arrangements in liberal democracies where the authorities use administrative law to circumvent or pervert the normal operation of criminal law. It will look at crimmigration and alien detention of citizens.

\section{Regimes in Democratic Decay and the Dual State}

\subsection{Contemporary Authoritarian Rule}

Recently Tom Gerald Daly mapped the landscape of the burgeoning literature on the phenomenon called democratic decay, rule of law backsliding or authoritarianism. ${ }^{5}$ On the basis of this mapping exercise he comes up with a summary definition of democratic decay or authoritarianism, namely "the incremental degradation of the structures and substance of liberal constitutional democracy". The notion of 'structures' refers to "democratic institutions such as courts, human rights commissions and ombudsmen, as well as political parties, media, and NGOs." 6 The tactics that contribute to this so-called degradation of the structures of liberal constitutional democracy have been well documented and criticized by human rights bodies, NGOs and scholars. ${ }^{7}$ Probably one of the most recent, comprehensive and detailed country studies is Sadurski's legal analysis

\footnotetext{
4 Though the literature on authoritarian rule is truly global, I concentrate on the European experience and in particular the administrative law of the EU Member States.

5 T. Daly, 'Democratic Decay: Conceptualising an Emerging Research Field' Hague Journal on the Rule of Law (2019) 11:9-36.

6 Daly, 17.

7 For references to reports and literature see, inter alia: T. Daly; J. Meierhenrich, The Remnants of the Rechtsstaat. An Ethnography of Nazi Law (OUP, 2018), especially Chapter 9; W. Sadurski, Poland's Constitutional Breakdown (OUP, 2019), Ch. 9; K. Scheppele (2018), 'Autocratic Legalism' 85 The University of Chicago Law Review 545. The tactics largely correspond with a recent influential analysis of indicators of democratic decay by S. Levitsky and D. Ziblatt in their How Democracies Die. (Viking/ Penguin Random House Books, 2018), 21-24.
} 
of the authoritarian tactics deployed in Poland. First, paralyzing any constitutional review of the regime's legislative and executive actions. Then packing constitutional and higher courts with judges loyal to the regime, thereby paving the way for judicial activism endorsing the platform of the majority regime. ${ }^{8}$ Second, the regime seeks to control independent media outlets by firing independent and critical journalists, editors and managers employed by the state media. Or by privatizing and selling state media outlets to investors linked to the regime. ${ }^{9}$ Third, the regime marginalizes civil society by cutting off subsidies, limiting the right to demonstrate, and deliberately failing to protect opponents against harassment and attacks by supporters of the regime. ${ }^{10}$ Members of civil society are fined and prosecuted for voicing their dissent in order to deter other dissenters from openly protesting. More generally, under the guise of combating terrorism, new laws grant authorities extensive competences to collect personal data of citizens. Also criminal law rules of evidence are amended in order to admit evidence in court that has been acquired illegally. Finally, regimes in democratic decay seek to control the economic sphere and by the same token economically marginalizing opponents. ${ }^{11}$ The regime may dismiss opponents working in the public administration. State-owned companies may be privatized and sold off to investors linked to the regime. Alternatively, when the opponents are working in the private sector, the regime may target them by structurally withdrawing or refusing economic permits. Also, the regime may structurally favour allies when awarding government contracts.

Contrary to the authoritarian regimes of the last century, the tactics of contemporary regimes in democratic decay are not outright repressive and totalitarian. ${ }^{12}$ They are not repressive in the sense of being physically coercive. The measures are mostly purely legal and do not involve the direct use of physical force and violence against opponents. Neither are the regimes defending the measures on the basis of a political ideology that seeks to identify and eliminate an existential enemy (cf. capitalists, bourgeois intellectuals, communists, Jews, etc.). Their political platform is not supposed to dominate all aspects and principles of public and private life. In effect, rather than eliminating political opponents, the regimes 'merely' seek to marginalize them. The upshot for the regimes is that they can claim to defend political pluralism and allow political dissent. Furthermore, since the regimes want to benefit from the legitimacy of the rule of law, they still rule through legal institutions and legal instruments. And although observers have clearly shown that the above-mentioned authoritarian tactics do not satisfy minimal formal conceptions of the rule of law, let alone any substantive notions of lawfulness, the regimes continue to make active use of legal institutions and legal instruments.

\footnotetext{
8 Sadurski, Chapters 3-4.

9 Sadurski, Chapter 5.

10 Sadurski, Chapters 5-6.

11 Sadurski, Chapter 5; Scheppele, 576.

12 Scheppele, 573-579.
} 


\subsection{Dual State}

A particularly insightful way to understand the role of the law in authoritarian regimes is the concept of the dual state. ${ }^{13}$ Jens Meierhenrich has recently revived the concept by drawing scholarly attention to Ernst Fraenkel's unique work, the Dual State. ${ }^{14}$ Fraenkel conducted a thorough analysis of the first 5-6 years of the legal system in Nazi Germany. Fraenkel, a Jewish lawyer, practised law himself in Germany up to $1938 .{ }^{15}$ He gives us a look into the workings of the court system under Nazi rule from the perspective of a practising lawyer while adding historical and conceptual analyses. Fraenkel's central finding is that the Nazi legal order was best understood as a dual state: a normative and a prerogative state. ${ }^{16}$ The prerogative state is headed by the political government and is solely aimed at the realization of the ideology of the Nazi party. Accordingly, the prerogative state is not bound by positive law and the actions of the prerogative state are not subject to review by the courts or in any event not by the ordinary courts. The competences and actions of the Gestapo, e.g. arrests and detentions of political enemies, were prominent examples of the prerogative state. The normative state is headed by the (non-political) bureaucratic administration. It must guarantee the proper functioning of the normal tasks of the state that are not governed by the prerogative state. It covers criminal justice of non-political crimes, private law matters, economic regulation, etc. The normative state is bound by positive law and the actions of the administration are subject to judicial review by the normal courts (insofar as such judicial review is provided for by positive law). ${ }^{17}$ The normative state was supposed to govern and protect the lives of the true deserving German citizens. It was not intended to protect the enemies of the German people. However, in practice the latter may receive collateral or indirect legal protection under the normative state. For example, Jews who were still participating in social and economic life could receive the normal protection of contract and labour law, because they had still social and economic ties with non-Jews. Targeting the Jews would then also adversely affect the legal position of non-Jews. But from the moment Jews were completely marginalized and the social

\footnotetext{
13 To clarify matters, for me the concept of the dual state was helpful to highlight the problematic features of administrative law. But the central concern of this article, namely the authoritarian or illiberal potential of administrative law techniques, does not rely on the aptitude of the dual state concept. Readers that may be distracted by this conceptual framework can skip Sects. 2.2-2.3 and proceed immediately to Sect. 3.

${ }^{14}$ J. Meierhenrich, The Remnants of the Rechtsstaat. An Ethnography of Nazi Law (Oxford: Oxford University Press, 2018).

15 J. Meierhenrich, 'An Ethnography of Nazi Law: The Intellectual Foundations of Ernst Fraenkel's Theory of Dictatorship' in E. Fraenkel, The Dual State: A Contribution to the Theory of Dictatorship, translated by E. A. Shils, with an Introduction by Jens Meierhenrich (Oxford: Oxford University Press, [1941], 2017), pp. xxvii-lxxxi.

${ }^{16}$ E. Fraenkel, The Dual State: A Contribution to the Theory of Dictatorship, Part. I, Chapters I and III.

${ }^{17}$ The so-called Enumerationsprinzip meant that in many of the German Länder there was still no general individual right to a judicial review of all types of administrative actions. Stolleis, 64 .
} 
and economic ties with non-Jews were severed, there was no need to grant Jews the protection of the normative state. ${ }^{18}$

Although the normative and prerogative state are distinct, they are deeply connected. Firstly, there is an absolute hierarchy. There is in principle no matter governed by the normative state in which the prerogative state may not intervene and take over. However, as Fraenkel's analysis of the case law shows, depending on the stage of development of the dual state, the courts of the normative state may temporarily resist such intervention and takeover. ${ }^{19}$ Secondly, though the prerogative state depends on the normative state's capacity to take care of the normal business of administration, the latter does not represent a separate distinct ethical entity. It means that though the normative state may be bound by positive law, it does not have an ethical logic of its own: its ultimate logic and function is to serve the prerogative state. So the lesson from Fraenkel is that the normative state may occasionally temper and slowdown the prerogative state, but it will never work as a bulwark against the prerogative state. ${ }^{20}$

Meierhenrich has slightly adapted Fraenkel's depiction of the dual state in order to use it as a paradigm for analyzing contemporary authoritarian regimes. ${ }^{21}$ In my reading of Meierhenrich's version of the dual state there is no absolute hierarchy between the prerogative and normative state. ${ }^{22}$ The power of the prerogative state to potentially intervene in every area of the normative state is crucial in totalitarian and repressive regimes. It seems less relevant to some of the contemporary regimes in democratic decay. Under the adapted version of the dual state the normative and prerogative state are thus more like coeval regimes. Still, for Meierhenrich the normative state is an essential ingredient of any successful authoritarian regime. In fact it is the normative state that helps to keep an authoritarian regime in place. It can provide minimal legitimacy to the majority of subjects. The normative state caters for output legitimacy by ensuring a minimal effectiveness of the normal tasks of the administration. And it caters for procedural legitimacy by upholding legality as a minimal form of the rule of law. So under the dual state of the Nazi regime the legality provided by the normative state was subordinate to the prerogative state. By contrast, in contemporary regimes in democratic decay that are neither totalitarian nor outright repressive, legality constitutes a crucial instrument of authoritarian rule.

The dual state is not merely a theoretical paradigm to be used by scholars trying to understand the workings of contemporary regimes in democratic decay. ${ }^{23}$ The logic

\footnotetext{
18 Fraenkel, 89-91.

19 Fraenkel discusses cases where the normal courts resisted Nazi interpretations that went against the letter or the spirit of positive law. The typical reasoning of the courts was not to reject the Nazi ideology per se, but a positivistic interpretation that the Nazi interpretation was simply not transposed into positive law by a statute or an explicit decree of the Führer. The courts argued that in the absence of such an explicit act or decree they could actually risk going against the will of the people and the Führer. Fraenkel, 85 .

20 Meierhenrich aptly uses the verb to temper instead of to constrain, Meierhenrich (2018), 231.

21 J. Meierhenrich (2018), p. 245 and generally Chapter 9.

22 Meierhenrich finds the normative and prerogative state to be 'independent yet interrelated'. Idem.

23 See for example the speculations about whether the developments in Poland and Hungary amount to a kind of dual state as described by Fraenkel in M. Gersdorf and M. Pilich (2020), 'Judges and Representatives of the People: a Polish Perspective' 16 European Constitutional Law Review, 348-349 and J.-W. Müller, 'Reflections on Europe's 'Rule of Law Crises', in P. Kjaer and N. Olsen (eds), Critical Theories of Crisis in Europe. From Weimar to the Euro (London: Rowman \& Littlefield, 2016), 166-167.
} 
of the dual state has penetrated the very reasoning of the ECJ. Recently, the Court has ruled that Member States cannot refuse to execute an European Arrest Warrant issued by Poland without conducting a specific and precise verification of whether the person to be surrendered runs a risk of a breach of his/her fundamental rights, even if there is evidence of systemic deficiencies concerning the independence of the judiciary in Poland. ${ }^{24}$ According to the ECJ evidence of systemic deficiencies in judicial independence does not mean that all judges or all courts lack judicial independence. ${ }^{25}$ Or in the words of the Advocate General an automatic refusal of an EAW 'could be construed as discrediting the professional work of all judges in the Republic of Poland. ${ }^{26}$ The reasoning of the Court and the Advocate General is understandable. But it also inadvertently recognizes and legitimizes a dual state in Poland: while some people may structurally be deprived of the protection of the law, this will not compromise the legal system as a whole because there are still independent judges who keep the normative state operational in Poland. With this judgment in its pocket the Polish regime can decide freely who will benefit from the normative state and who will receive prerogative state treatment.

\subsection{A Prerogative State Within the Normative State}

The essence of a dual state is that the daily lives of the majority of citizens are governed by the normative state, while opponents of the regime are governed by the prerogative state. ${ }^{27}$ It means that the citizens who support, cooperate with or do not oppose the regime must have the guarantee that their lives are governed by a normal properly functioning legal system, that is predictable, treats all citizens equally before the law and protects the rights of citizens against unlawful acts by fellow citizens and the state. ${ }^{28}$ By contrast, when it comes to opponents, the regime should have its hands free to treat them as it deems fit. The difficulty is of course to ensure that the distinction between loyalists and opponents is sufficiently clear and stable for both citizens and bureaucrats. In repressive and totalitarian systems of the last century the regime can rely on an ideological and existential friend/enemy distinction to single out opponents. ${ }^{29}$ Moreover, in those systems the prerogative state always took priority over the normative state. Furthermore, if legal instruments fell

\footnotetext{
${ }^{24}$ ECJ, in Joined Cases C-354/20 PPU and C-412/20 PPU, 17 December 2020, ECLI:EU:C:2020:1033, par. 70.

25 Par. 41.

26 Opinion of Advocate General, Campos Sánchez-Bordona, 12 November 2020, Joined Cases C-354/20 PPU and C-412/20 PPU, ECLI:EU:C:2020:925, par. 51 (emphasis in the original).

27 I use the term citizen for reasons of style. The more correct legal term is legal subjects ('Rechtssubjekt', 'sujet de droit'), because the normative state applies to both citizens and non-citizens.

28 See for a study of an arguably relatively well functioning normative state regime, K. Hendley, Everyday Law in Russia (Cornell University Press, 2017).

29 Arguably a repressive and totalitarian regime can never make good on the promise of a normative state precisely because it is always conditional on the prerogative state not intervening with the normal operation of the law.
} 
short, the regime could simply act through de facto means, physical violence being the most spectacular form of de facto action.

Contemporary regimes in democratic decay cannot single out their opponents overtly in terms of existential enemies. Moreover, formally there are no prerogative state institutions in place. Formally all citizens, including opponents of the regime, are governed by the normative state. So how can contemporary regimes single out opponents and treat them differently while maintaining the veneer of legality? How can contemporary regimes in democratic decay effectively use the law to marginalize their opponents while avoiding that the opponents are also protected by the law?

Rather than having a dual state whereby the prerogative state is distinct from and sovereign over the normative state, the prerogative state must operate from within the normative state. The legal system must be such that the regime can operate with the legitimacy of the law but without its constraints, or at least without constraints that are too strong. There are at least two sources of legality in a contemporary dual state: legislation and judicial review. The authoritarian measures must take the form of and/ or based on legislation. This is a relatively easy task as the contemporary regimes in democratic decay typically enjoy an absolute legislative majority. So they can legislate at will. The second source of legality is judicial review. The regimes can remove the authoritarian stain from their authoritarian tactics if they can show that their measures have been checked and approved by the courts. To this effect, the measures must be susceptible to review by the courts that check all relevant aspects of the measures in question. In other words, at least on paper, virtually all measures must be susceptible to judicial review while no relevant aspect of the measures should remain unchecked. But if this judicial review is truly universal (all measures) and comprehensive (all relevant aspects) then the authoritarian tactics may not pass judicial scrutiny. A contemporary regime in democratic decay needs a kind of law that allows the regime to claim that its measures are subject to judicial review, while it still has sufficient leeway to marginalize the opposition. In other words, a dual state whereby the tools of the prerogative state have become quotidian features of the normative state: a system allowing the regime to have the cake and eat it. It is the claim of this paper that administrative law constitutes such a dual state in and of itself.

\section{Administrative Law as a Dual State}

\subsection{Scholarly Context}

Critical observers correctly characterize the authoritarian tactics of contemporary regimes in democratic decay as undermining and abusing constitutional law. In effect, the rule of law decay is most of all a problem of constitutional and fundamental rights law. Inadvertently, this almost exclusive constitutional law and fundamental rights perspective may say something about administrative law. While it makes complete sense to speak of 'Poland's Constitutional Breakdown', ${ }^{30}$ it seems

\footnotetext{
${ }^{30}$ See the title of Sadurski's excellent legal analysis of Poland's democratic and rule of law breakdown.
} 
less obvious to speak of 'The Breakdown of Administrative Law in Poland'. Apparently, there is nothing wrong with the authoritarian tactics from the perspective of administrative law. To put it differently, regimes in democratic decay are violating constitutional law but they are not undermining administrative law. ${ }^{31}$

One may argue that this exclusive constitutional law perspective is simply explained by the constitutional law nature of the authoritarian measures. Indeed, the most spectacular and shocking measures by the regimes, namely the complete destruction of the independence of the constitutional and higher courts, are constitutional law matters. But if we consider the example of authoritarian tactics in Poland mentioned above, we can see that the bulk consists of administrative law measures. The regime controls the media and marginalizes independent media through largely administrative law legislation and administrative decisions, as opposed to constitutional, criminal and civil law. Marginalizing civil society is largely done through administrative law decisions, e.g. denying subsidies, refusing to authorize a demonstration. Also the anti-terrorism competences allowing large-scale data surveillance are not criminal law but administrative law competences. When the regimes seek to control the economic sphere and by the same token economically marginalizing opponents, they do so mainly through administrative law measures (e.g. hiring and firing civil servants, the refusal and withdrawal of economic permits, privatization, public procurement). Interestingly, when the regimes mobilize criminal law against opponents they do not use criminal law in its classic function of having a court of law establish whether or not a suspect has committed a criminal offence. They actually use criminal law as a means of putting pressure on opponents and create a chilling effect. Often the regimes abandon the criminal proceedings before the case makes it to the courts. ${ }^{32}$ In other words, the regimes can only use criminal law to their benefit by openly distorting its normal functions.

Administrative law seems to play a crucial role in the daily operations of contemporary regimes in democratic decay. However, when scholars analyze authoritarian regimes, they do not examine the distinctive role of administrative law in authoritarian regimes. Surely they inevitably include descriptions and examples of administrative law arrangements and practices that are operative in a particular authoritarian

\footnotetext{
31 I am not denying that constitutional and administrative law may be intrinsically connected. In fact, this is one of the perennial theoretical themes of modern administrative law. For an almost exhaustive comparative, analytical and historical study of the various positions in both constitutional and administrative law theory, see L. Heuschling, 'Verwaltungsrecht und Verfassungsrecht' in A. von Bogdandy, S. Cassese and P. Huber (eds) Verwaltungsrecht in Europa: Grundlagen in Handbuch Ius Publicum Europeanum vol. III (C.F. Müller, 2010, Heidelberg), 505-550. According to some scholars constitutional values and safeguards are or should be an integral part of positive administrative law. If so then undermining the constitutional law necessarily implies undermining administrative law. But what has been compromised are the constitutional values within administrative law. It seems that administrative law does not have 'constitutional values' of its own which are not also already present in constitutional law proper. It means that when a regimes breaks down the constitution, administrative law does not have the resources of its own to resist authoritarian tactics. On paper the principles of good administration could be an example of constitutional values that are an exclusive product of administrative law. But in practice when it comes to authoritarian and illiberal measures the principles of good administration have turned out to be rather toothless.

32 Sadurski, 154.
} 
regime ${ }^{33}$ For example, Ginsburg's invaluable contribution explains why authoritarian rulers have an interest in subjecting themselves to administrative law. ${ }^{34}$ But he does not explain what is so distinctive about administrative law compared to criminal and civil law that makes it particularly convenient for authoritarian regimes. In an insightful overview of administrative law in Hungary, Kovacs and Scheppele point out the limitations to individual legal protection under Hungarian administrative law. ${ }^{35}$ They seem to suggest that these limitations are partially a legacy of the socialist era. They do not explain to what extent this may be a feature shared by the administrative law of European jurisdictions with a long liberal tradition. Fraenkel himself considered the workings of the administrative courts during the Nazi regime as part of the normative state, standing on an equal footing with the criminal and civil law courts. ${ }^{36} \mathrm{He}$ did not see administrative law as combining the prerogative and normative state elements in a single legal field. In the context of the dual state in contemporary regimes in democratic decay, Meierhenrich emphasizes the importance of investigating the more quotidian operations of the normative state. ${ }^{37}$ But he does not construe administrative law as distinctively problematic let alone as a dual state order in and of itself. Similarly, Hendley's excellent study of 'everyday law' in post-communist Russia does not discuss the special role of administrative law. ${ }^{38}$

In fact Fraenkel's study and later legal historical studies on administrative courts during the Nazi regime seem to contradict my claim that administrative law distinctively caters to authoritarian rule. ${ }^{39}$ Firstly, there are many cases whereby administrative courts ruled against the interest of the Nazi regime. ${ }^{40}$ Secondly, the regime successfully sought to shield all matters it deemed political from any review by the

\footnotetext{
${ }^{33}$ For example, the various country studies in T. Ginsburg \& T. Moustafa (Eds.), Rule by Law: The Politics of Courts in Authoritarian Regimes (Cambridge: Cambridge University Press, 2008). Neither does Jothie Rajah's excellent account of the emergence of an authoritarian rule of law in Singapore identify administrative law as distinctively problematic. See J. Rajah, Authoritarian Rule of Law. Legislation, Discourse and Legitimacy in Singapore (Cambridge, Cambridge University Press, 2012). Probably this has also to do with the specific origins of Singapore's legal system which from the outset had a thin and fragile rule of law basis (51-52). In fact Rajah mentions how at some point in time activist lawyers deployed administrative law to bring mandamus orders against state actors (175).

${ }^{34}$ T. Ginsburg, 'Administrative Law and the Judicial Control of Agents in Authoritarian Regimes' in T. Ginsburg \& T. Moustafa (Eds.), Rule by Law: The Politics of Courts in Authoritarian Regimes (pp. 58-72). Cambridge: Cambridge University Press, 2008.

${ }^{35}$ K. Kovács and K. Lane Scheppele, 'Hungary's post-socialists administrative law regimes' in Rose Ackermann and Peter Lindseth, Comparative Administrative Law (2nd ed) (Edward Elgar, Cheltenham, 2017), 134-135.

${ }^{36}$ Fraenkel, Part. I, Chapters I and III.

${ }^{37}$ Meierhenrich (2018), p. 250, endnote 140.

${ }^{38}$ Since Hendley focuses on the operations of the normative state, the fact that administrative law combines normative and prerogative state elements is not directly relevant for her general claim about everyday law in Russia. K. Hendley, Everyday Law in Russia (Cornell University Press, 2017).

${ }^{39}$ L. Frege, 'Der Status des Preussischen Oberverwaltungsgerichts und die Standhaftigkeit seiner Rechtsprechung auf politischen Gebiet' in H. Külz and R. Naumann (eds.). Staatbürger und Staatgewalt, vol. 1, (Karlsruhe, C.F. Müller, 1963), 131-155; M. Stolleis, 'Die Verwaltingsgerichtsbarkeit im Nationalsozialismus' in H.-U. Erichsen e.a. (eds) System des verwaltungsgerichtlichen Rechtsschutzes. Festschrift für Christian-Friedrich Menger (Heymans, Cologne, 1985), 57-80.

${ }^{40}$ Stolleis, 71.
} 
administrative courts. ${ }^{41}$ In other words, the regime did perceive judicial review by the administrative courts as a genuine constraint. However, there are also many cases whereby the courts ruled in favour of the regime where it could have done otherwise. ${ }^{42}$ Also legal historians are cautious to note that the literature only discusses case law from the higher administrative courts. But probably many unlawful acts were never challenged before a court or ended at first instance only. ${ }^{43}$ More importantly, what is really missing in the literature is how even normal features of administrative law already accommodated much of the regime's plans. For example, contemporary scholars have characterized the 1935 ruling by the highest Prussian administrative court as an example of the rule of law resisting the regime. ${ }^{44}$ The court ruled that 'Gypsies' were also subjects of the German State and were thus not governed by some sort of state of exception. Therefore the authorities could not chase them away from one place to another. But what scholars have failed to see is how on the basis of administrative law the court left ample room for the regime to take measures targeting and marginalizing 'Gypsies' short of chasing them away. The court recognized the power of the police to combat the threats to public order resulting naturally from the Gypsy lifestyle. ${ }^{45}$ Whereby it should be noted that the courts would only check marginally if in fact there was a threat to public order.

Interestingly, in the US context some experts in public law have argued that there is something distinctively special about administrative law that makes it either a sort of 'state of the exception' law or simply unlawful. ${ }^{46}$ Still these positions are only remotely related to my claim that administrative law constitutes a dual state. The debates are primarily about administrative legislation, i.e. the generally binding legal rules and regulations issued by the administration as opposed to Congress. ${ }^{47}$ Also the discussions are embedded in the particularities of US constitutional case law and legal doctrine. The authors do not use the paradigm of the dual state and they do not link administrative law to contemporary regimes in democratic decay. Yet an important commonality between these debates in the US and my claim is a focus on the distinctive nature of administrative law.

Thus the novelty of this section is that so far scholars have not noticed how normal administrative law constitutes a dual state in and of itself that caters for

\footnotetext{
${ }^{41}$ Stolleis, 62 and 79.

42 Frege, 146-150.

${ }^{43}$ Stolleis, 80.

${ }^{44}$ D. Merten, 'Geschichte der Verwaltungsgerichtsbarkeit in Preussen' in K.-L. Sommermann and B. Schaffarzik (eds), Handbuch der Geschichte der Verwaltungsgerichtsbarkeit in Deutschland und Europa (Berlin, Springer 2019), 300.

45 'Freilich ist die Polizei berechtigt, den aus den eigentümlichen Lebensgewohnheiten der Zigeuner und ihren Nomadentum entspringenden besonderen polizeilichen Gefahren entgegenzutreten.' PrOVGE 97, 177 (5 December 1935) cited in Stolleis, 71-72.

46 A. Vermeule (2009), 'Our Schmittian Administrative Law', 122 Harvard Law Review 1095 ; P. Hamburger, Is Administrative Law Unlawful (Chicago, The Chicago University Press, 2014).

47 Taking cue from Hamburger, Evan Bernick challenges the current practice of judicial deference to fact-finding by administrative agencies. Yet he argues in favour of full judicial review only when core private rights are involved. He is thinking mainly of administrative fines that infringe the general right to property and administrative measures depriving a person of her liberty. E. Bernick (2018), 'Is Judicial Deference to Agency Fact-Finding Unlawful?' 16 The Georgetown Journal of Law and Policy 27.
} 
authoritarian tactics of regimes in democratic decay. Administrative law has the distinctive quality of offering regimes a legality bonus while legally allowing them to marginalize opponents. The crucial insight is that the authoritarian potential of administrative law is not the product of authoritarian rule, but comes from the elements from normal administrative law shared by all jurisdictions in Europe, liberal and illiberal alike. ${ }^{48}$

Below this article identifies characteristic elements of administrative law that produce the dual state: universal and comprehensive judicial review of administrative action, the presumption of the legality of the administrative act, the privilege of execution of the administration and judicial deference to policy discretion and fact-finding by the administration. These are all uncontroversial elements of normal administrative law as practised and taught in European jurisdictions. ${ }^{49}$ Again, I am not claiming that administrative law is authoritarian or will necessarily lead to authoritarian rule. Neither am I saying that through administrative law authorities can have it fully their way. For example, regimes in democratic decay directly seek to determine the organization and composition of administrative courts, in order to ensure that administrative courts will decide in their favor in cases that matter

\footnotetext{
${ }^{48}$ The intensive scrutiny of facts by German administrative courts seems an exception among European jurisdictions. It is also largely a break from Germany's pre-WWII administrative law tradition. G. Nolte (1994), 'General Principles of German and European Administrative Law - A Comparison in Historical Perspective' 57 The Modern Law Review 2, 198-204.

${ }^{49}$ I focus on continental EU Member States covering two large families of administrative law, namely French and German administrative law. For reasons of space and my lack of competence, I have omitted administrative law jurisdiction in common law systems. For Germany and France I relied on textbooks used in legal education and by legal professionals. Germany: H. Maurer and C. Waldhoff, Allgemeines Verwaltungsrecht (Munich, C.H. Beck, 2020); F. Hufen, Verwaltungsprozessrecht (Munich, C.H. Beck, 2019); M. Fehling, B. Kastner and R. Störmer (eds.), Verwaltungsrecht: VwVfG, VwGO, Nebengesetze: Handkommentar (Baden-Baden, Nomos, 2016); S. Detterbeck, Allgemeines Verwaltungsrecht: mit Verwaltungsprozessrecht (Munich, C.H. Beck, 2016); W. Hoffmann-Riem and E. Schmidt-Assmann, Grundlagen des Verwaltungsrecht, vol. 2-3, (Munich, C.H. Beck 2012). France: J. Waline, Droit administratif (Paris, Dalloz, 2018); P. Gonod, Droit administratif general (Paris, Dalloz, 2018); D. Truchet, Droit administratif (Paris, Presses Universitaires de France, 2017); P.-L. Frier and J. Petit, Droit administratif (Paris, L.G.D.J., 2014). For administrative law in other European jurisdictions I relied on the country studies in the following edited volumes of comparative administrative law: A. von Bogdandy, P. Huber and L. Marcusson (eds), Verwaltungsgerichtbarkeit in Europa: Institutionen und Verfahren in Handbuch Ius Publicum Europeanum vol. VIII (C.F. Müller, 2019, Heidelberg); A. von Bogdandy, S. Cassese and P. Huber (eds) Verwaltungsrecht in Europa: Grundzüge in Handbuch Ius Publicum Europeanum vol. V (C.F. Müller, 2014, Heidelberg); J.-B. Auby and J. Dutheil de la Rochère (eds.), Traité de droit administrative européen (Brussels, Bruylant, 2014); J. Schwarze, European Administrative Law (Office for Official Publications of the European Communities, 2006); R. Seerden (ed), Comparative Administrative Law. Administrative Law of the European Union, its Member States and the United States (Intersentia, Cambridge, 2018). To have a comparative view of the scope and intensity of judicial review by the administrative courts in Europe I used: M. Kayser, 'Rechtsschutz und Kontrolle' in A. von Bogdandy, S. Cassese and M. Huber (eds) Verwaltungsrecht in Europa: Grundzüge in Handbuch Ius Publicum Europeanum vol. V (C.F. Müller, 2014, Heidelberg), 1047-1130. For a more practice-based understanding of judicial review I relied on A. Vasco Barrón and C. Günther, 'General Report. Administrative Law in the European Union Single Case Decision-Making' ReNEUAL I Seminar Cologne 2-4 December 2018.
} 
the most to them. ${ }^{50}$ This suggests that, without partisan and biased administrative courts, in and of itself administrative law does not fully cater for the whims of the regime. Also I am not denying how historically speaking, modern administrative law and modern rule of law (or rather Rechtsstaat or état de droit) coevally emerged as a response to the police state in the German territories and the administrative state in France. ${ }^{51}$ But I do claim that administrative law contains elements that are distinctively well suited to cater for authoritarian tactics.

\subsection{Access to Justice, the Presumption of Legality and the Privilege of Execution}

The crux of the dual state is that there must be sufficient normative state elements present to produce legal legitimacy. For judicial protection by administrative courts the normative state element consists of the fact that judicial review is universal, albeit limited. Today, virtually all administrative acts are subject to judicial review. Few are the acts that are formally excluded from judicial review (e.g. 'actes de gouvernment' in France). Jurisdictions that do not allow a judicial review of general legislation issued by the administration still allow a review of individual administrative decisions based on such administrative legislation (e.g. Germany and the Netherlands). Also, jurisdictions that only allow citizens to challenge administrative acts if they can invoke a subjective right tend to interpret the notion of subjective rights extensively and thus granting standing in most cases. Furthermore, the threshold for accessing the administrative courts is relatively low, e.g. in many jurisdictions the court fees are low and representation by a professional lawyer is not mandatory. So thanks to administrative law no act by the administration is immune from judicial scrutiny. In this respect, administrative law ensures that public authorities, including regimes in democratic decay, satisfy a quintessential requirement of the rule of law, namely that all acts by the administration are bound by law. ${ }^{52}$

Although access to the administrative courts is largely universal, in practice judicial protection by the administrative courts is often cumbersome or simply obsolete. In fact, the normative state character of universal access to administrative courts is tempered by prerogative state elements inherent in administrative law. This has to

\footnotetext{
50 M. Bernatt (2019), 'Illiberal Populism: Competition Law at Risk?' Working Paper, 24 January 2019, available at SSRN: https://ssrn.com/abstract=3321719, sections IV.B.1-2, 27-36. In this respect, it should be noted that the reforms introduced by the regimes pertain to the organization and composition of administrative courts, but not the actual legal techniques and concepts of administrative law.

51 P. Costa, 'The Rule of Law: a Historical Introduction' in P. Costa and D. Zanilo (eds) The Rule of Law. History, Theory and Criticism (Dordrecht: Springer, 2007), 93-102; L. Mannori and B. Sordi, 'Science of Administration and Administrative Law', in P. Grossi, H. Hofmann, and D. Canale (eds) A Treatise of Legal Philosophy and General Jurisprudence. Vol. 9: A History of the Philosophy of Law in the Civil Law World, 1600-1900 (Dordrecht: Springer, 2009), 242-248.

52 To be clear, this distinctive quality of administrative law is only useful to the extent that the regime still seeks a legality bonus through judicial review. It is also possible that a regime simply excludes a judicial review of some authoritarian measures. See the widespread detention without trial in Singapore in Rajah at 176, 215-216.
} 
do with quintessential characteristics of an administrative act under administrative law: the presumption of legality and the privilege of execution. ${ }^{53}$ Administrative acts benefit from the presumption of legality. It means that they are considered legally valid and binding from the moment they are communicated to the norm addressees. Citizens must immediately comply with the administrative act even if they have reasons to believe that the act is in fact unlawful. Moreover, subject to certain conditions, the administration may execute, even with force, the administrative decision without seeking an executory title from a court. In most jurisdictions, if the citizen challenges the administrative decision before an administrative court, his appeal will not have suspensive effect, unless he obtains a suspension order from a court in a separate procedure. The direct consequence is that the ball is put fully in the court of the citizen. Moreover, the administration can already establish facts on the ground. As a result, judicial protection will often be simply too burdensome or come too late. In fact, the basic logic of administrative law allows the administration to act unlawfully pending possible legal challenges. ${ }^{54}$ As Walter Jellinek aptly put it: the administration has the great privilege of being permitted to make mistakes. ${ }^{55}$ This basic feature of administrative law significantly limits the de facto effectiveness of judicial protection.

It is easy to see how regimes can use this basic feature of administrative law to marginalize opponents. For example, even when the unlawful withdrawal or refusal of an economic permit to opponents is invalidated by a court, the economic harm has often already occurred. Also depending on the jurisdiction and the type of case, the administrative court may only invalidate the refusal but not issue a license in lieu of the administration or order the administration to issue such a licence. ${ }^{56}$ It stands in stark contrast to criminal law, whereby enforcement must be ordered by a court after a trial, with rules of evidence in favour of the citizen. Even pre-trial (criminal law) measures seriously infringing basic rights and liberties are subject to regular review by a judge.

The universal access to administrative courts in combination with the distinctive features of the administrative act partially shapes the dual state nature of administrative law. The universal access to administrative courts allows authorities to claim the legality bonus since all their acts are potentially subject to judicial review. By the same token, the presumption of legality and the privilege of execution often make

\footnotetext{
53 For a comparative analysis, see G. Napolitano, 'Handlungsformen' §89, in A. von Bogdandy, S. Cassese and P. Huber (eds) Verwaltungsrecht in Europa: Grundzüge in Handbuch Ius Publicum Europeanum vol. V (C.F. Müller, 2014, Heidelberg), 995-996, 998.

54 The only fundamental counterweight is forbearance, i.e. 'the idea that politicians should exercise restraint in deploying their institutional prerogatives.' Levitsky and Ziblatt, How Democracies Die, 8-9.

55 'Der hoheitliche Staat und die ihm gleichstehenden Träger öffentlicher Gewalt haben das grosse Vorrecht, sich irren zu dürfen.' W. Jellinek, Verwaltungsrecht. 2nd ed. (Berlin, Verlag Julius Springer, 1929),

56 The possibility to confront opponents with faits accomplis against which legal action is prohibitive or simply obsolete explains that even when formally the prerogative state elements are not sovereign over the normative state elements (as was the case under the dual state described by Fraenkel), the modern version is still very effective.
} 
the access to administrative courts cumbersome and obsolete allowing regimes to target opponents even if doing so is unlawful: in most cases judicial protection will only come after the harm is done.

\subsection{Policy Discretion}

Another key characteristic of administrative law is that the administration often has policy discretion. Often statutes conferring powers on the administration allow for some policy discretion. In such cases the administration has the liberty to choose between reasonable courses of action based on ranking priorities and weighting the interests at stake. ${ }^{57}$ The weighting of interests is based on the policy preferences of the administration. Policy discretion is a textbook feature of administrative law. It is probably the most debated feature of administrative law in the literature precisely because it may grant too much liberty to the administration paving the way for the arbitrary exercise of powers. In this respect, policy discretion is the characteristic of administrative law that is most likely to be associated with the prerogative state. Depending on the wording of the statutes conferring discretionary powers on the administration, discretionary powers permit regimes in democratic decay to freely choose courses of action targeting opponents. Furthermore, administrative courts when reviewing administrative decisions must defer to the weighting of interests conducted by the administration. The courts cannot substitute the policy preferences of the administration with their own.

Policy discretion is not a purely prerogative state matter. Administrative law ensures that policy discretion is embedded in the normative state. Firstly, policy discretion must be provided for by the laws conferring competences on the administration. Secondly, the exercise of policy discretion is not immune from judicial review. Though the administrative courts must show deference to the administration's exercise of policy discretion, they do review policy discretion. The administration's liberty under policy discretion is not absolute. The administration may only choose between reasonable courses of action. In other words, the courts will check whether the exercise of discretion was reasonable. As a result, while exercising their policy discretion authorities can claim the legality bonus because the discretionary powers have a statutory basis and are subject to judicial review, albeit this is limited.

It is important to note that when courts scrutinize an authoritarian-like measure at the level of an individual case the individual administrative decision will probably pass the reasonableness test. For example, when the administration has some policy discretion when deciding to grant or refuse a subsidy to an NGO, it will be difficult for the court to detect that the administration is abusing its discretion to target NGOs that are critical of the regime. Only if a court could

\footnotetext{
57 Policy discretion may be granted at two levels. First, the administration may have liberty to act or not to act if the factual conditions for action are satisfied (if $\mathrm{X}$ is the case, then the administration may do $\mathrm{Y}$ ). Secondly, the administration may have liberty to choose between certain types of measures (if $X$ then the administration may do $\mathrm{Y} 1$ or $\mathrm{Y} 2 / \mathrm{Y}$ or Z/'what is necessary').
} 
assess the subsidy decisions on aggregate may it detect a structural bias against critical NGOs and favouritism vis-à-vis NGOs supporting the regime. But administrative courts look at individual cases only and it is impossible for the courts to have a representative picture of all administrative measures affecting opponents, as they will only see the unfavourable decisions that make it to the courts.

The judicial review of policy discretion contributes to the dual state character of administrative law in ways that would be more difficult under civil law. The crux is that administrative law grants authorities a legality bonus because even the exercise of policy discretion is susceptible to judicial review. But since the judicial review of policy discretion is limited to a reasonableness test, administrative law grants authorities sufficient leeway to target opponents.

Judicial deference to policy discretion is strictly speaking not distinctive for administrative law. In some jurisdictions, depending on the type of claim, civil courts hear cases against the administration and will conduct a marginal review of the administration's exercise of policy discretion. Still, this is rather the exception. Even in jurisdictions were civil judges hear cases against the administration, the civil judge mainly acts as a back-up judge and summary judge (thus a judge only competent to issue a provisional order and who does not assess the full factual and legal merits of the case). This means that by and large most cases against the administration are heard by administrative courts and governed by administrative law. In some jurisdictions, the administrative courts may even have to adapt normal civil law rules in order to make them suitable for the special nature of the administration. ${ }^{58}$

\subsection{Factual Discretion and Judicial Deference to Administrative Fact-Finding}

Judicial deference to fact-finding Depending on the jurisdiction and the particular policy field, the administration may not only have policy discretion, but it may also have a certain factual discretion, namely the liberty to choose between reasonable assessments of the facts. As a direct corollary of the administration's factual discretion the administrative courts may defer to the factual assessment by the administration, i.e. judicial deference to fact-finding by the administration. It means that the administrative court will not make its own assessment of the facts but relies on the fact-finding carried out by the administration.

\footnotetext{
58 This topic is about the competence of the civil judge in actions against the administration. This highly complex matter is in a way central theme of the emergence and development of modern administrative law. For recent insightful comparative perspective on the matter, see W. Konijnenbelt, 'IV.a.38 De gewone rechter en het bestuursrecht in Frankrijk' in M. Feteris e.a. (eds), De burgerlijke rechter in het publiekrecht (Deventer: Wolters Kluwer, 2015) [Kluwer navigator digital version without original page numbers]; B. Roozendaal, 'IV.a.39 De burgerlijke rechter en het publiekrecht in Duitsland' in M. Feteris e.a. (eds), De burgerlijke rechter in het publiekrecht (Deventer: Wolters Kluwer, 2015) [Kluwer navigator digital version without original page numbers].
} 
It remains difficult to gauge exactly the level of judicial deference in the various jurisdictions. ${ }^{59}$ First, the level may vary over time and per area of administrative law. For example, in areas where the plaintiffs have enormous litigation resources (e.g. environmental, competition and telecom law), the factual review by the administrative courts tends to be more intensive than in areas where the plaintiffs are single individuals with scarce litigation resources (e.g. migration and asylum law). Second, when certain fundamental rights are at stake judicial deference to fact-finding must be limited or is even prohibited, at least on paper (e.g. Art. 3 ECHR). Third, the phenomenon is clouded by some conceptual confusions. In all jurisdictions administrative courts are competent to review the facts and to legally qualify those facts. In many jurisdictions administrative courts can decide cases de novo. These competences are easily mistaken for the complete antithesis of judicial deference to administrative fact-finding. However, when a court reviews and qualifies the facts, it does not mean that the court establishes the facts of the case based on its own investigation, collection and appreciation of evidence. Similarly the power to make a de novo decision does not mean that the court establishes the facts de novo.

The fact that the level of judicial deference to administrative fact-finding is difficult to pinpoint exactly should not distract us from its omnipresence in virtually all European jurisdictions, with the notable exception of Germany. ${ }^{60}$ The case law of the ECtHR is probably a good indicator of the ubiquity of judicial deference to administrative fact-finding in European jurisdictions. In the context of its Art. 6 ECHR (the right to a fair trial, civil limb) case law the Court reports that it is often the case in relation to administrative-law appeals in the member States of the Council of Europe that the extent of judicial review over the facts of a case is limited. ${ }^{61}$ Moreover, the Court sanctions this limited examination of the facts because in the Court's view Art. 6 only requires that a domestic (administrative) court has jurisdiction to

\footnotetext{
${ }^{59}$ For example, when trying to gauge the level of judicial deference shown by the French Conseil d'État Jacques Ziller observes: 'ist umstritten, ob und inwieweit der Verwaltungrichter eine judicial deference gegenüber Verwalting und Politik zeigt. Die ungleichen Ansichten diesbezüglich resultieren inbesondere aus rechtsvergleichender Arbeit. Meiner Meinung nach kann hierzu keine allgemeingültige Aussage gegeben werden'. J. Ziller, 'Verwaltungsgerichtsbarkeit in Frankreich' in A. von Bogdandy, P. Huber and L. Marcusson (eds), Verwaltungsgerichtbarkeit in Europa: Institutionen und Verfahren in Handbuch Ius Publicum Europeanum vol. VIII (C.F. Müller, 2019, Heidelberg), 225. Even otherwise insightful comparative theoretical, doctrinal or practical studies cannot offer any real clarity in the matter. See respectively: F. Bignami, 'Comparative Administrative Law' in M. Bussani and U. Mattei (eds), The Cambridge Companion to Comparative Law (Cambridge University Press, 2012), 145-170; Kayser (2014), 1086-1087, 1101; Vasco Barrón and C. Günther (2018).

${ }^{60}$ The existence of judicial deference to administrative fact-finding de lege lata does not mean that some jurists have voiced criticism - de lege ferenda - against too much judicial deference to administrative fact-finding. For example in the Netherlands some jurists call for an administration and administrative judiciary that can keep a better eye on the concrete (and thus factual) context of administrative decisions. For an excellent overview of the debate and a balanced defence of this position, see L. van den Berge, 'Responsief bestuursrecht', in Maatwerk. Preadviezen no 164. VAR Vereniging voor Bestuursrecht. Boom juridisch 2020,7-61, especially at 50. Still, proponents of a responsive administrative law do not call for abandoning judicial deference to administrative fact-finding completely but rather for tempering it depending on the context.

${ }^{61}$ ECtHR, Ramos Nunes de Carvalho e Sá v. Portugal [GC], nos. 55391/13 and 2 others, 6 November 2018, par. 178 (emphasis added).
} 
examine all questions of fact [..] relevant to the dispute before it'. ${ }^{62}$ This requirement is already satisfied if the court has "exercised "sufficient jurisdiction" or provided "sufficient review", ${ }^{63}$ In effect, the Court holds that administrative courts may conduct an even more limited review of the facts if the administrative decision involved a 'specialised issue requiring professional knowledge or experience', provided that the administration respected procedural safeguards during the administrative factfinding. ${ }^{64}$ Similarly, in its Art. 3 ECHR (the prohibition of torture and inhumane or degrading treatment) case law the Court by implication holds that administrative courts need not conduct a rigorous scrutiny of a claim against the administration if the matter does not involve a possible infringement of Art. 3 ECHR. ${ }^{65}$

The case law of the ECtHR corresponds with the general legal mechanics of judicial deference to administrative fact-finding. The principle of legality requires that the administration may only act within the remit of powers conferred upon it. Typically, this includes the satisfaction of certain factual conditions ('if [factual condition $\mathrm{X}]$ is the case then the administration may/shall $\mathrm{Y}^{\prime}$ ). For the sake of analytical clarity we may distinguish between four types of facts. Firstly, facts that can be ascertained precisely (e.g. the height of a building, the date of an email, the number of children, etc.). Secondly, facts that can be ascertained by approximation only. Certain facts cannot be established precisely because of imperfect and incomplete information and evidence (e.g. annual income, the size of the market, regional NOx output, etc.). Thirdly, the ascertainment of facts that involve a prediction (e.g. the future environmental impact, the future impact of a merger on prices). Fourthly, the ascertainment of facts that involve evaluative judgments. Here the observer must allocate certain weight to the evidence in order to conclude whether (the criteria for) the factual conditions are satisfied. The exact weight will depend on the preferences of the observer. To be sure, the evaluative facts are not necessarily subjective or a matter of policy discretion. They are not subjective in the sense that the factual conditions and what counts as relevant evidence of the factual conditions can be determined objectively. Yet the weighting of the evidence cannot be done precisely. They are not a matter of policy discretion because establishing an evaluative fact is not necessarily a matter of balancing and weighting of interests. It is typically not about determining whether an interest takes priority over another interest, but rather about whether the threshold for satisfying a certain criterion has been met. For example, in the context of an art subsidy having international experience is a criterion that is clearly objective. And the selection commission can objectively come to the conclusion that an exhibition abroad counts as relevant evidence for the criterion of international experience. However, putting points to the evidence on a scale of 1-5 involves an evaluation. This evaluative assessment is informed by the preferences of the commission but it does not involve policy discretion in the sense of the weighting of interests. Similarly, when assessing whether a crowd constitutes a risk

\footnotetext{
62 Ibid. par. 176, with references to the relevant case law (emphasis added).

63 Ibid. par. 177, with reference to the relevant case law.

64 Ibid. par. 179, with references to the relevant case law.

65 See Jabari v. Turkey 11 July 2000, par. 50.
} 
to public order, the administration can work with objective risk indicators: the number of people involved, the number of males, the location, the time of day, remarks uttered by the crowd, perceived levels of intoxication, social media communications. From the indicators the relevance of the evidence can be determined objectively. However, the actual weight to be allocated to the evidence is a matter of evaluative judgment. But it is not a matter of policy discretion in the sense of the weighting of interests. Only when the administration has established the level of risk does it come to the actual policy choice of weighting and prioritizing the different interests at stake, e.g. public order versus the right to assembly. For sure, many practitioners and critical scholars will argue that in reality the distinction between evaluative facts and policy discretion is not so neat and tidy. Still for our purposes it is helpful to maintain this analytical distinction.

When it comes to the type one facts that can be ascertained precisely there can only be one right and correct answer to the question about what the facts are. Hence, the administration has no factual discretion and the administrative courts can conduct a comprehensive check of whether the factual conditions are satisfied. When it comes to the ascertainment of facts involving estimations, predictions and evaluations there may be more than one right or reasonable answer to the question about what the facts are. This means that the administration may have some factual discretion. Depending on the jurisdiction and the nature of the case, administrative courts will conduct only a limited review of the facts. Often administrative courts will limit themselves to checking whether the administration has ascertained the factual conditions properly, rather than ascertaining the facts themselves. The review boils down to a kind of reasonableness test where the court checks whether the fact-finding by the administration was reasonable.

The underlying rationale is that the court is less or not better equipped than the administration to ascertain facts involving approximations, predictions or evaluations. ${ }^{66}$ By contrast, the administration is considered to have special expertise. First, the administration has the expertise of proximity. It is directly confronted with the situation on the ground. Second, the administration has knowledge of other decisions taken in similar cases, while the court only sees the decisions that are challenged before a court. Third, civil servants have particular technical skills and knowledge of the functional policy area (e.g. building safety, environmental protection) through higher education, vocational training or on the job experience.

Judicial deference as a dual state Similar to policy discretion, regimes in democratic decay can use the factual discretion to target political opponents while benefiting from the legality bonus since the exercise of the factual discretion is subject to judicial review, albeit limited. The administration of a regime in democratic decay can make factual assessments that turn out to be structurally unfavourable to political opponents. But as long as the administration's approximations, predictions and evaluations of the facts are reasonable, they will pass

\footnotetext{
${ }^{66}$ I am simply restating here the textbook rationale for judicial deference to fact-finding. I do not necessarily agree with all reasons.
} 
judicial scrutiny. Again crucial here is that judicial scrutiny of the fact-finding takes place, albeit only to a limited extent. In other words, judicial deference to fact-finding combines normative and prerogative state elements in a single legal arrangement.

Judicial deference to fact-finding is distinctive for administrative law. It stands in stark contrast to the presumption of innocence under criminal law, whereby it is not the prosecution but the criminal court that establishes the facts. Furthermore, when the court establishes the facts it must apply the highest legal standard of proof, namely beyond reasonable doubt. The strong procedural safeguards under criminal law are justified because of criminal law's punitive character: criminal liability may result in imposing suffering on the convicted citizen. Most administrative measures are not punitive. They may be merely regulatory, e.g. the refusal of an economic licence. Or they may be restorative, e.g. the dispersal of a crowd in order to restore public order. However, regimes in democratic decay may find such non-punitive measures to be immensely effective in order to target and marginalize political opponents, without being hindered by the procedural safeguards of ordinary criminal law.

The dual state logic is reinforced by the underlying rationale of the judicial deference to fact-finding by the administration, namely expertise. A proven technique to increase legal legitimacy is to de-politicize policy areas and turn them into a-political matters of purely technical expertise. ${ }^{67}$ As a result, it brings matters completely under the normal business of law and administration, i.e. the normative state. But here administrative law shows its distinctive dual state nature. While one would expect technical matters to be most suitable for objective and impartial scrutiny by the courts, administrative law does exactly the opposite: expertise warrants judicial deference. In fact, under administrative law the authorities can have it both ways. In one way, authorities can benefit from judicial deference because the administrative decisions are political or policy matters. In another way, the authorities can benefit from judicial deference precisely because the matters are a-political par excellence, namely technical matters involving expertise.

\footnotetext{
${ }^{67}$ For example, the later Franco regime deliberately labelled the bulk of governmental tasks and public life as a-political, neutral and technical. It was a strategy that was necessary in country that was politically deeply divided. Only a fraction of the state was preoccupied with political matters. Neutral and a-political life was governed by the normal rules of administrative, civil and criminal administration and justice. It was the institutional framework that was necessary for the economic project of the Franco regime from the 1960s onwards. C. Pinkele, 'Plus ça change: The Interaction between the Legal System and Political Change in Francoist Spain' International Political Science Review (1992), Vol. 13, No. 3, 285-300; J. Toharia, 'Judicial Independence in an Authoritarian Regime: The Case of Contemporary Spain' Law \& Society Review, Vol. 9, No. 3 (Spring, 1975), pp. 475-496. By the same token, so-called neutral or technical measures can be political or prerogative measures in disguise. This is clearly the case in the context of the regulation of economic life. Sometimes even economic matters are considered too politically sensitive for the regime to directly address and are therefore delegated to the courts. T. Moustafa and T. Ginsburg, 'Introduction: The Functions of Courts in Authoritarian Politics' in T. Ginsburg \& T. Moustafa (Eds.), Rule by Law: The Politics of Courts in Authoritarian Regimes (Cambridge: Cambridge University Press, 2008), 9-10.
} 


\section{Dual State Techniques in Liberal Democracies}

So far I have tried to show how standard features of administrative law turn administrative law into a kind of dual state in and of itself. Administrative law offers regimes in democratic decay a legality bonus because under administrative law all administrative actions must be based on law and are susceptible to judicial review covering all relevant aspects of the decision. By the same token since judicial review is often burdensome or obsolete and only has a limited intensity, administrative law grants the regimes ample leeway to target opponents. Administrative law is much better equipped to produce a dual state than civil and criminal law. As a result, many of the authoritarian tactics are cast in administrative law legislation and decisions rather than civil and criminal law. But administrative law techniques are not only used by regimes in democratic decay to take authoritarian measures. Also in liberal democracies we can see how administrative law is used to circumvent the normal operation of criminal and civil law. Of course, contrary to the regimes in democratic decay, liberal democracies do not target and marginalize political opponents. But also in liberal democracies administrative law is used to infringe on rights of individuals that would otherwise not be possible under normal criminal and civil law.

A whole set of legal arrangements comes to mind if we look afresh at administrative law. For example, how the ECtHR accommodates the logic of administrative law when it finds without any serious substantiation that nationality cases do not involve a civil right. As a result, administrative decisions depriving a citizen of his nationality in order to combat terrorism do not fall under Art. 6 ECHR (civil limb) (the right to a fair trial).$^{68}$ Looking at the distinctive role of administrative law may help us understand the actual techniques underlying certain policies that have been analyzed so far primarily from an EU law, human rights law and social science perspective, e.g. the expulsion of Roma by French authorities. ${ }^{69}$

Not only does the logic of administrative law allow authorities to circumvent civil law, it may also penetrate and pervert civil law. For example, in the Netherlands the public prosecutor has the power to demand the invalidation of a marriage if a party entered into the marriage not with a view to fulfilling the marital obligations, but to obtain legal admission and residence in the Netherlands. ${ }^{70}$ In other words, migration policy considerations that are governed by administrative law determine the validity

\footnotetext{
${ }^{68}$ See S. Mantu (2015) Contingent Citizenship: The Law and Practice of Citizenship Deprivation in International,European and National Perspectives, Brill/Nijhoff at 111-113.

${ }^{69}$ See H. O'Nions (2011), 'Roma Expulsions and Discrimination: The Elephant in Brussels' 13 European Journal of Migration and Law, 361-388; I. Vrăbiescu (2019), 'Devised to punish: Policing, detaining and deporting Romanians from France' European Journal of Criminology, 1-18.

${ }^{70}$ See Art. 1:71a Civil Code introduced by the Wet van 2 juni 1994 tot wijziging van de Titels 4 en 5 van Boek 1 van het Burgerlijk Wetboek en van de Wet gemeentelijke basisadministratie persoonsgegevens (Act of 2 June 1994 amending Titles 4 and 5 of the Civil Code and the Municipal Databse (Personal Files) Act) Stb. 1994, 405. For a critical analysis see H.U. Jessurun d'Oliveira, Het migratierecht en zijn dynamiek: Het artefact van het 'schijnhuwelijk' (Deventer, Kluwer, 1998). To be sure, in practice this provision remained a dead letter. For the European migration law context, see B. de Hart (2017), 'The Europeanization of Love. The Marriage of Convenience in European Migration Law' 19 European Journal of Migration and Law, 281-306.
} 
of private law arrangements. Administrative law may also be used to circumvent the normal application of criminal law. The so-called 'administrative displacement' mentioned in the introduction to this article is a case in point. For reasons of space I will restrict myself to briefly discussing two other examples where administrative law circumvents and perverts the normal operation of the criminal law: crimmigration and the alien detention of citizens. ${ }^{71}$

\subsection{Crimmigration}

Administrative law does not only circumvent the normal civil law institutions, it also circumvents and perverts criminal law. The process whereby criminal law and criminal law-type measures are deployed in order to ensure effective migration policies, especially combating irregular migration, has been labelled crimmigration. The topic has become an academic discipline of its own. For our purposes two aspects of crimmigration directly point to dual state tactics. Firstly, in the context of migration law enforcement, authorities are increasingly using intrusive and coercive measures that are comparable to criminal enforcement measures (e.g. detention, searches, identity checks). But criminal procedural law imposes relatively strict conditions and constraints on the use of such measures. Most importantly the law enforcement agents must have a reasonable suspicion (probable cause) that the person has committed an offence. And when the measure involves detention the offence must be serious. It is often the case that these conditions are not satisfied in a migration context. Therefore many states have introduced legislation authorizing the agencies to take such measures without the strict conditions and constraints of criminal procedural law. The vehicle that makes this possible is administrative law. Thus migration law, i.e. administrative law, grants authorities the power to take coercive and intrusive measures that are similar if not identical to criminal law measures but without the procedural safeguards of criminal law. This is what Legomsky already in 2007 called the 'asymmetric incorporation of criminal justice norms' in migration law. ${ }^{72}$

Secondly, not only does migration law incorporate criminal law measures without providing the safeguards. It also hollows out criminal law from within. Today many states have introduced criminal penalties for violations of migration law. On paper the defendant will receive a proper criminal trial. Yet due to the nature of the offence

\footnotetext{
${ }^{71}$ The counterintuitive observation is that in terms of legal protection people are often better off when their case is governed by criminal law as opposed to administrative law. An extreme version of this observation is the practice by lawyers during the Nazi regime to obtain a conviction from an ordinary criminal court in order to prevent their client from being sent to a concentration camp by the Gestapo. Fraenkel, 245-246.

72 SH Legomsky,'The New Path of Immigration Law: Asymmetric Incorporation of Criminal Justice Norms', 64 Wash. \& Lee L. Rev. 469 (2007), https://scholarlycommons.law.wlu.edu/wlulr/vol64/iss2/3. The reverse phenomenon is now also considered to be a form of crimmigration: authorities using migration law tools for criminal justice purposes. The tactic of using administrative law to circumvent criminal law constraints has recently been observed in an extensive field study of the Royal Netherlands Marechaussee when conducting internal border checks. M. van der Woude \& J. van der Leun, (2017) 'Crimmigration checks in the internal border areas of the EU: Finding the discretion that matters' European Journal of Criminology, Vol. 14(1) 27-45.
} 
most criminal law safeguards will be obsolete: the presumption of innocence, the burden of proof, the standard of proof, rules of evidence, etc. Normally a criminal court judge must conduct a full investigation of all relevant facts and points of law. However, when it comes to migration law offences the facts are already established by the migration authorities and are reviewed by the administrative court.

Let us consider a standard trajectory for a criminal migration case. A migrant is already present in the territory pending a decision on his application for an authorization to stay. The application is refused because the administration has found that the facts of the case did not satisfy the legal criteria and/or policy considerations (if the application did not involve a request for international protection). In combination with the refusal of the residence permit, the migrant also receives an order to leave the territory. The migrant may lodge an administrative appeal against the decisions. And when the higher administrative body still upholds the first decisions, the migrant can appeal before an administrative court. The administrative court must examine the facts and the points of law. However, if it is not an asylum case the administrative court may defer to the administration's fact-finding and policy considerations. And unless the case only involved type one facts that can be ascertained precisely and with certainty the court will primarily check the reasonableness of the facts and the soundness of the administrative fact-finding process; it will not establish the truth of the facts. If the first instance administrative court rejects the appeal the plaintiff may lodge a higher appeal. But the higher administrative court will show similar deference to the administrative fact-finding. It means that the administrative decisions refusing the permission to stay and ordering the migrant to leave the territory were subject to a judicial review at two instances. The administrative courts looked at all relevant facts. However, their review was limited in intensity. They did not establish that the facts were true beyond reasonable doubt.

Depending on the specific criminal legislation, remaining in the territory after having received an order to leave may constitute a criminal offence. ${ }^{73}$ If detected and arrested the migrant may face criminal prosecution. If so the criminal court will have to establish three facts: (1) the migrant remained in the territory after having received an order to return; (2) he was aware of his illegal stay (and the order to return); (3) there are no justified grounds for non-return. Apart from a third fact that could potentially require some factual investigation and assessment by the court, establishing the facts is really a formality. In effect, it has all the hallmarks of a formal offence. As a result the standard criminal law safeguards have become obsolete, especially the presumption of innocence with its burden of proof and high standard of proof. The facts that really mattered to the case and constitute the underlying

\footnotetext{
73 In some jurisdictions remaining in the territory after having received a re-entry ban constitutes a criminal offence (e.g. the Netherlands, France). The ECJ has recently ruled that the alien can only be punishable on the basis of a re-entry ban if he actually exits and re-enters the country. But the Court also explicitly reiterated the possibility for Member States to punish aliens remaining in the territory simply on the basis of their illegal status, irrespective of a re-entry ban, provided that an illegal stay is laid down in a criminal statute and that the alien has no justified ground for his non-return. JZ, 17 September 2020, C-806/18, ECLI:EU:C:2020:724, paras. 27-29, 34 and 35 referring to Achughbabian, 6 December 2011, C-329/11, ECLI:EU:C:2011:807, paras. 46, 48 and 50.
} 
basis for the criminal offence are the facts of the administrative decisions, a rejection of the application for permission to stay and the order to leave the territory. Yet when the administrative courts reviewed the facts underpinning the administrative decisions they did not apply the criminal law safeguards. Still, while the criminal court will simply defer to the formal validity of the administrative decisions and the authority of the administrative courts, the underlying facts of the case were not established beyond reasonable doubt.

This is an ideal dual state tactic because from the outside it bears all the hallmarks of lawfulness. Indeed, in some jurisdictions potentially five courts may look at the case. For example in the Netherlands two administrative courts (at first instance and the higher administrative court) and three ordinary courts (the first instance criminal court, the court of appeal and the Supreme Court, the latter only addressing points of law). And all the legal safeguards of administrative and criminal law are applied. But in reality the administrative law procedures hollow out the criminal law procedures completely. It is also an ideal dual state tactic because it is not at all exclusively reserved for migration law matters. The tactic applies to any form of the criminalization of administrative offences.

\subsection{Citizens in alien detention}

Under crimmigration I mentioned how authorities use administrative law to circumvent criminal law in order to effectively execute migration policies. Another tactic is to use migration law to circumvent criminal law in order to effectively execute criminal justice policies. The 'administrative displacement' mentioned in the Introduction to this article is one example. The detention of citizens on the basis of migration law in the Netherlands is another case in point. Since the beginning of 2000 political activists when participating in protests that are not authorized-for example during the evacuation of a squatted building by the police-have been refusing to disclose their identity when they are arrested by the police. Since the offence, namely disturbing the public order, is not serious enough for pre-trial detention, the police must release the activists without obtaining their identity which is necessary for further prosecution. In response the police started to detain activists on the basis of the Aliens Act. The Aliens Act does allow the detention of aliens if there is a reasonable suspicion that the alien in question is in the country illegally, has received an order to leave and seeks to avoid his expulsion. The conditions are cumulative. The authorities have reasoned that the conditions have been satisfied simply because the activists did not cooperate with the police in disclosing their identities. There were no factual indications that the legal conditions were satisfied. If anything, there were counter-indications, namely the activists spoke Dutch as native Dutch people do. In 2007 an activist placed in alien detention appealed to the administrative court. The administrative court ruled that the detention was illegal because of détournement de pouvoir. The Minister of Justice appealed before the Council of State, the highest administrative court. The latter overturned the lower court decision and ruled in favour of the administration. According to the highest administrative court the activist must bear the risks of his non-cooperation and the fact that he can speak Dutch 
does not necessarily exclude the possibility that he is an alien who has received an order to leave the territory. ${ }^{74}$

Only in 2012 after many more cases of citizens in alien detention did the highest administrative court overturn its earlier ruling and declared that this use of alien detention was outside the scope and objectives of the Aliens Act. ${ }^{75}$ Yet, in spite of this clear ruling in 2012, in 2015 the police again placed activists-this time students occupying administrative buildings of the University of Amsterdam-in alien detention. The officials acted openly against the clear ruling of the court. They therefore acted unlawfully. But the authorities were still invoking the law, namely the Aliens Act. After being released the protesters challenged the legality of their detention before an administrative court and obtained damages. Surprisingly the court only found that there were insufficient grounds for the detention on the basis of the Aliens Act. ${ }^{76}$ In spite of the pre-existing case law of the Council of State, the court did not find any bad faith, malign intent or gross negligence on behalf of the State to the effect that the use of the Aliens Act constituted a détournement du pouvoir or an abuse of authority.

The alien detention of citizens effectively illustrates how administrative law can cater for a dual state tactic. First, the authorities can claim to act, at least provisionally, in the name and on the basis of statutory law. Second, the authorities benefit from the second layer of the legality because the administrative decisions are reviewed by independent courts. Third, even when already found to be unlawful by the highest court, the authorities can still make use of the tactic because they have the benefit of the presumption of legality and the privilege of execution. The authorities do not need to seek prior approval from a court to place the protesters in alien detention. Finally, because the matter is now governed by administrative law, any reflexes associated with ordinary civil and especially criminal law are dumbed. Surely if the detention of the protesters was ordered by a criminal court which was clearly biased, used flawed and secret evidence, which did not hear the defendant, and which completely deferred to the fact-finding by the administration, criminal law experts would have raised the alarm. But since the matter has been transformed from a criminal law into an administrative law issue, authorities can detain protesters without a trial, let alone a fair trial. Criminal law experts could not even raise the alarm because the matter was outside their competence and was within the jurisdiction of the dual state of administrative law. Of course, the use of alien detention for citizens in the Netherlands is only one example. But the underlying administrative law mechanisms that allow authorities to circumvent the normal application of criminal law are present in all European jurisdictions and are potentially applicable to many policy areas.

\footnotetext{
74 Council of State, 2 April 2007, ECLI:NL:RVS:2007:BA2831.

75 Council of State, 1 February 2012, ECLI:NL:RVS:2012:BV2478.

76 Court of first instance The Hague, 30 April 2015, ECLI:NL:RBDHA:2015:5259.
} 


\section{Conclusions}

Scholars have aptly described how contemporary regimes in democratic decay are using the law to stay in power and marginalize political opposition. Some scholars have used the figure of the dual state to better understand how the regimes try to have it both ways. The regimes seek, on the one hand, the legality bonus and functional benefits of a normally functioning equitable and reliable legal system governed by the rule of law (normative state). On the other hand, they want to have the leeway to structurally target and marginalize opponents (prerogative state).

Scholars have also pointed out that many contemporary regimes in democratic decay are not totalitarian and outright repressive. Neither in those regimes is the prerogative state sovereign over the normative state. The paper explains that this means that the regimes cannot use ideological existential categories (e.g. communist, bourgeois, intellectual, Jew, homosexual, etc.) to distinguish between loyal citizens who must be governed by the normative state and opponents who must be governed by the prerogative state. 'A way out' for the regimes is to have a legal system where the prerogative state operates from within the normative state. The novelty of the article is that it identifies administrative law as being distinctively well-suited to cater for such a prerogative state within the normative state. In fact, in the paper I argue that administrative law constitutes a dual state in and of itself combining normative and prerogative state elements in a single area of law and in single legal arrangements.

Administrative law is distinctively apt to cater for a dual state compared to civil and criminal law because of some features that are typical of administrative law. On the basis of domestic administrative law textbooks and studies of comparative administrative law, the paper singles out features of administrative law that are considered uncontroversial and common to virtually all European jurisdictions. Under administrative law almost all administrative decisions are susceptible to judicial review covering all relevant aspects of a decision (points of law, facts and policy). This allows authorities to claim a legality bonus as all their decisions are subject to judicial scrutiny. By the same token, administrative law also grants regimes in democratic decay ample leeway to target and marginalize opponents. The presumption of legality and the privilege of (forced) execution often render judicial review practically cumbersome or obsolete. Furthermore, although the scope of judicial review by administrative courts is on paper comprehensive, due to judicial deference to policy discretion and judicial deference to administrative fact-finding the review remains superficial leaving ample leeway for the authorities.

The paper ends by drawing attention to the fact that the dual state nature of administrative law is not only an aspect of contemporary regimes in democratic decay, but that it is also a matter of concern in liberal democracies. The paper illustrated this point with two examples of how in liberal democracies administrative law is used to circumvent or pervert the normal operation of criminal law. My underlying normative point was to draw scholarly attention to the inherent authoritarian potential of administrative law. I certainly did not claim that administrative law is authoritarian or necessarily leads to an authoritarian rule of law. But I did argue that administrative law is distinctively better suited to cater for authoritarian rule than 
criminal and civil law. So in order to establish an authoritarian rule of law regimes must actively pursue a constitutional breakdown, but there is no need for them to also undermine administrative law. Apparently administrative law already suits their purposes just fine.

Acknowlegements I received invaluable comments and suggestions on this article and previous versions from Kati Cseres, Tom Daly, David Dyzenhaus, Betty de Hart, Luc Heuschling, Jens Meierhenrich, Joana Mendes, Marcelle Reneman, Thomas Spijkerboer, Béla Strauss, Marc de Wilde, participants of the Bergen aan Zoom conference 2020, participants at the conference in Lund 2020 organized by Vladislava Stoyanova and Stijn Smet and the participants of Centre for Legal Education and Social Theory Reading Group of the University of Wroclaw organized by Michal Stambulski. I am especially grateful to the three anonymous reviewers of this journal who clearly gave the manuscript a charitable, careful but critical reading.

Open Access This article is licensed under a Creative Commons Attribution 4.0 International License, which permits use, sharing, adaptation, distribution and reproduction in any medium or format, as long as you give appropriate credit to the original author(s) and the source, provide a link to the Creative Commons licence, and indicate if changes were made. The images or other third party material in this article are included in the article's Creative Commons licence, unless indicated otherwise in a credit line to the material. If material is not included in the article's Creative Commons licence and your intended use is not permitted by statutory regulation or exceeds the permitted use, you will need to obtain permission directly from the copyright holder. To view a copy of this licence, visit http://creativecommons.org/licen ses/by/4.0\%.

Publisher's Note Springer Nature remains neutral with regard to jurisdictional claims in published maps and institutional affiliations. 